Theoretical Underpinnings of the Other Social Effects Account

C. Mark Dunning and Susan Durden

September 2007 


\section{Theoretical Underpinnings of the Other Social Effects Account}

C. Mark Dunning

Marstel-Day, LLC

509-1 Jackson Street

Fredericksburg, VA 22401

Susan Durden

U.S. Army Corps of Engineers

Institute for Water Resources

7701 Telegraph Road

Alexandria, VA 22315

Final report

Approved for public release; distribution is unlimited.

Prepared for U.S. Army Corps of Engineers

Washington, DC 20314-1000

Monitored by Coastal and Hydraulics Laboratory

U.S. Army Engineer Research and Development Center

Vicksburg, MS 39180-6199 


\begin{abstract}
While water resources planning has primarily been focused on enhancing economic well-being as portrayed in the National Economic Development (NED) account, well-being is a multifaceted concept grounded in human needs that includes distributive justice, social connectedness, equality, and health and safety considerations, in addition to economic well-being factors. Information on these multiple dimensions of well-being is increasingly being used by Federal agencies, the World Bank, and other countries to provide a more comprehensive understanding of quality of life and livability issues. A water resources planning process that incorporates a multidimensional conception of wellbeing positively influences the degree to which water resources solutions will bejudged as effective, acceptable, and fair. The planning process envisioned in the U.S. Army Corps of Engineers' Engineering Circular on collaborative planning is consistent with the conceptions of well-being portrayed in this paper. To be most effective in this emerging planning framework, social factors information addressed in the "Other Social Effects" (OSE) account should be integrated into the planning process to provide information about social issues of concern to help shape planning objectives, develop and evaluate alternatives, and work toward solutions. The role of the OSE practitioner should be one of "action researcher," helping all interested parties to use OSE information to contribute to decision-making. A number of actions will be needed to ensure that OSE information is substantively used in water resources planning. Training and policy clarification forums will be necessary to overcome the lack of understanding and skepticism among planners steeped in NED-centric planning about OSE information and its value. Frameworks will need to be evaluated and defined which incorporate OSE in the decision-making process. Establishing an OSE center of expertise within the Corps of Engineers would also help in raising the profile of human factors information and would establish a base for advancing water resourcesoriented human factors knowledge. Finally, the Corps needs to re-engage with the growing body of practice in human dimensions, social factors, and quality of life work located in other Federal agencies, the World Bank, the European Union, other organizations, and academia.
\end{abstract}

DISCLAIMER: The contents of this report are not to be used for advertising, publication, or promotional purposes. Citation of trade names does not constitute an official endorsement or approval of the use of such commercial products. All product names and trademarks cited are the property of their respective owners. The findings of this report are not to be construed as an official Department of the Army position unless so designated by other authorized documents.

DESTROY THIS REPORT WHEN NO LONGER NEEDED. DO NOT RETURN IT TO THE ORIGINATOR. 


\section{Contents}

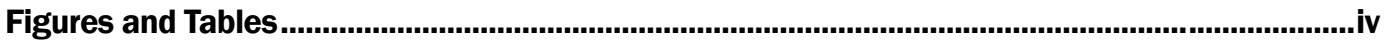

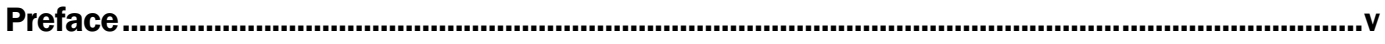

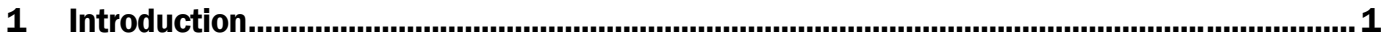

2 What Do "Social Effects" Mean? Why Are Social Effects Important? ................................ 2

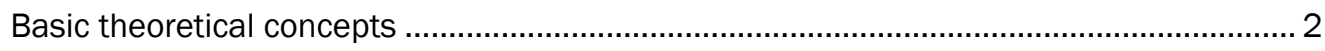

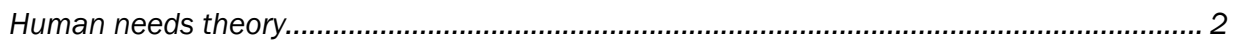

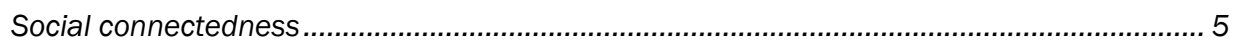

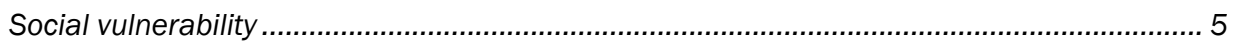

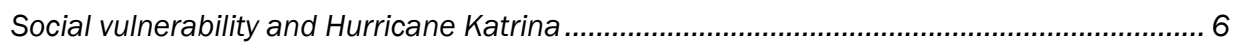

Environmental justice ............................................................................................. 7

Environmental justice in the Comprehensive Everglades Restoration Project....................... 8

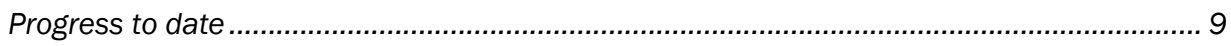

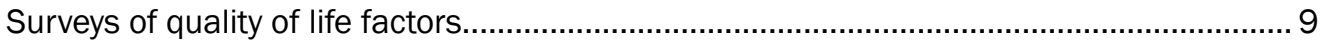

European system of social indicators (EUSI) ..............................................................10

Economist intelligence unit's quality of life index (2005)................................................. 10

New Zealand quality of life indicators........................................................................ 11

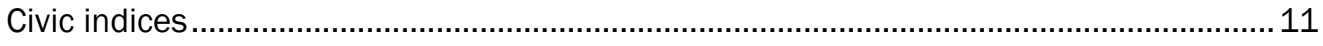

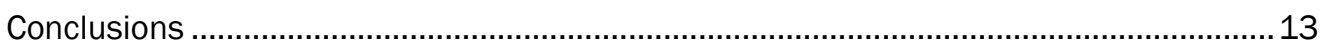

3 The Decline of Interest in and Concern with the OSE Account.........................................15

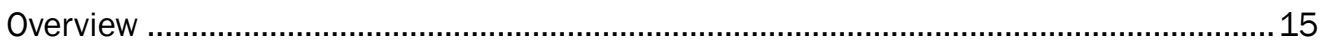

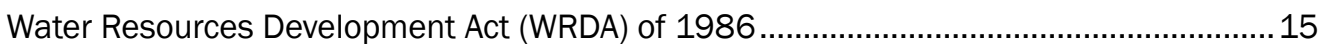

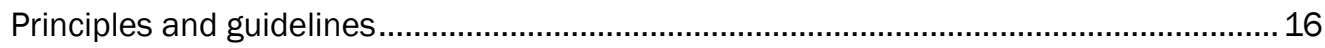

Failure of social assessment to deliver useful results .................................................. 18

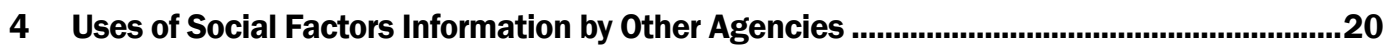

National Oceanographic and Atmospheric Administration (NOAA), Coastal

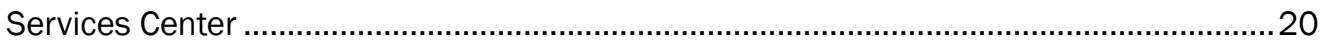

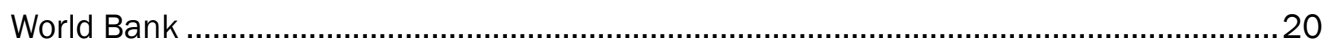

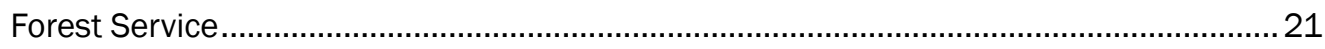

Natural Resource Conservation Service (NRCS) …................................................... 21

Tennessee Valley Authority (TVA) .......................................................................... 22

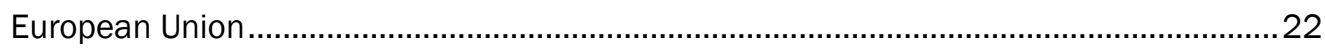

5 Social Effects Information in the Collaborative Planning Paradigm................................24

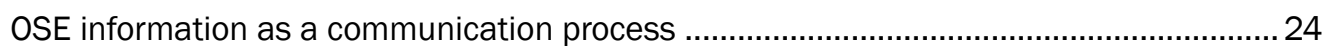

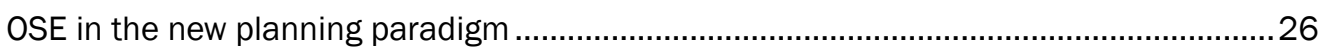

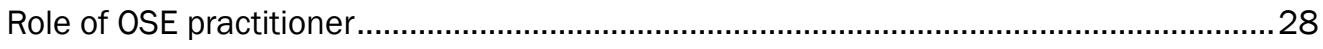

Challenges in the use of OSE information ...............................................................29 


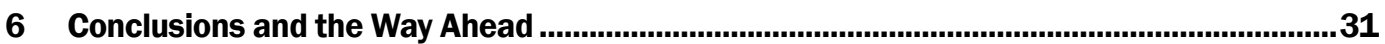

References.......................................................................................................................................33

Appendix A: Comparison of Key Theoretical OSE Concepts and Variables with Current

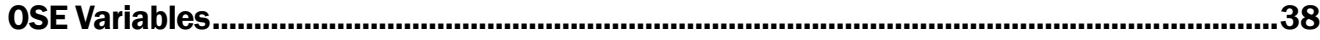

Appendix B: A Brief History of Congressional and Executive Branch Concern with

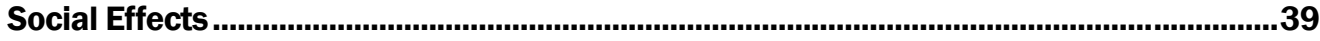

Appendix C: Toward a Collaborative Planning Paradigm ...............................................................43

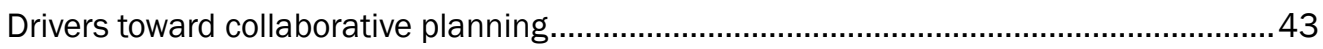

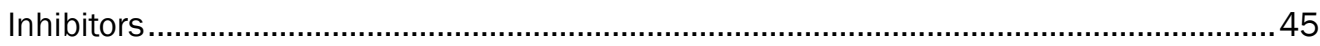

Report Documentation Page

\section{Figures and Tables}

\section{Figures}

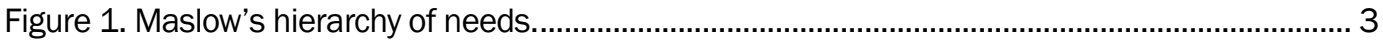

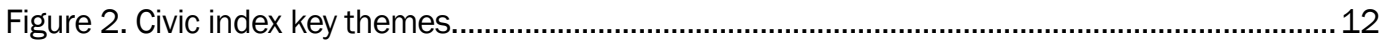

Figure 3. Constellation of well-being concerns..................................................................... 14

Figure 4. Some key OSE questions of concern. ............................................................................. 25

\section{Tables}

Table 1. A Comparison of the role of OSE information in the current planning framework with the four-account planning framework. 


\section{Preface}

This report was prepared to support the application of collaborative planning, particularly use of the Other Social Effects account in project analysis, in the Corps of Engineers Civil Works program as presented in Engineering Circular (EC) 1105-2-409 "Planning in a Collaborative Environment" (31 May 05). This work was performed by the Institute for Water Resources (IWR), under the direction of Lillian Almodovar, in support of Headquarters, U.S. Army Corps of Engineers (HQUSACE). Harry Kitch is the HQUSACE proponent. The report was prepared by Dr. Mark Dunning of Marstel-Day, LLC, 509-1J ackson St., Fredericksburg, VA 22401 under Contract Number: W91278-06-D-0025, Task Order 0008. Susan Durden of IWR served as the technical monitor for the report. For further information contact Lillian Almodovar, 703428-6021, Lillian.Almodovar@usace.army.mil, or Dr. Dunning, 703-9662398, md@marstel-day.com.

This paper represents the views of the authors. It is does not purport to be official policy of the Department of the Army.

Funding was provided by the U.S. Army Engineer Research and Development Center (ERDC), Flood and Coastal Storm Damage Reduction (FCSDR) Program, monitored by the Coastal and Hydraulics Laboratory (CHL). Dr. J ack E. Davis was Technical Director of the FCSDR Program. Thomas W. Richardson was Director of CHL. Dr. William D. Martin was Deputy Director of CHL.

COL Richard B. J enkins was Commander and Executive Director of ERDC. Dr. J ames R. Houston was Director. 


\section{Introduction}

This report describes the role that information on the social effects of water resources problems and solutions should play in water resources planning. A concern for social effects associated with water resources development and management has long been part of Federal water resources planning guidance, appearing as the "Social Well-Being Account" in the 1972 "Principles and Standards" (Water Resources Council), and later (and currently) as the Other Social Effects (OSE) account in the Principles and Guidelines (P\&G) adopted in 1983 (Water Resources Council). Since the adoption of the P\&G, there has been a tendency to discount the roles and importance of OSE factors in water resources planning and instead focus attention on National Economic Development (NED) benefit/ cost procedures, which were given primacy in the P\&G and in the U.S. Army Corps of Engineers (USACE) water resources policies.

However, new guidance being promulgated and implemented principally, EC 1105-2-409, "Planning in a Collaborative Environment" (USACE 2005) - places much greater emphasis on the importance of including a broad range of considerations in planning. In addition to NED, other considerations, including social factors addressed in the OSE account, are to be used to develop appropriate water resources solutions. There is, thus, a need for a broad reintroduction to the OSE account to provide information about key social concepts and their importance in water resources planning.

The primary purposes of this report are to provide some grounding in the theoretical basis for why social factors need to be considered in planning and also to provide a conceptual framework for how to do so. Work to follow will focus on methodologies and measurement approaches (Durden and Almodovar 2006). 


\section{What Do "Social Effects" Mean? Why Are Social Effects Important?}

\section{Basic theoretical concepts}

Social effects in a general sense refer to a concern for how the constituents of life that influence personal and group definitions of satisfaction, wellbeing, and happiness are affected by some condition or proposed intervention. But what are these constituents of life that are vital to personal and group well-being? Various theorists have focused on this question and some of their work is discussed. Three key organizing concepts about well-being are presented: human needs theory, social connectedness, and social vulnerability.

\section{Human needs theory}

The foundational concept in human needs theory is that people must have a number of essentials to survive and thrive. The best-known human needs theorist, Abraham Maslow, postulated a hierarchy of needs starting with basic physiological requirements for survival - food, water, and shelter (Maslow 1943). As basic needs are met, people seek to satisfy successively higher-order needs in the following general order: physiological needs, safety, love/ belonging, status (esteem), and actualization (Figure 1). Another basic point is that the satisfaction of needs occurs in a social context - i.e., the satisfaction of needs requires the involvement of others.

Other needs theorists have perceived human needs as being less a hierarchy and more of an ensemble of essentials for human development that are sought simultaneously (National Research Council 2002). To the categories of needs defined by Maslow, human needs theorists exploring the roots of conflict have included a number of additional essential human needs (Burgess and Burgess 2005): 


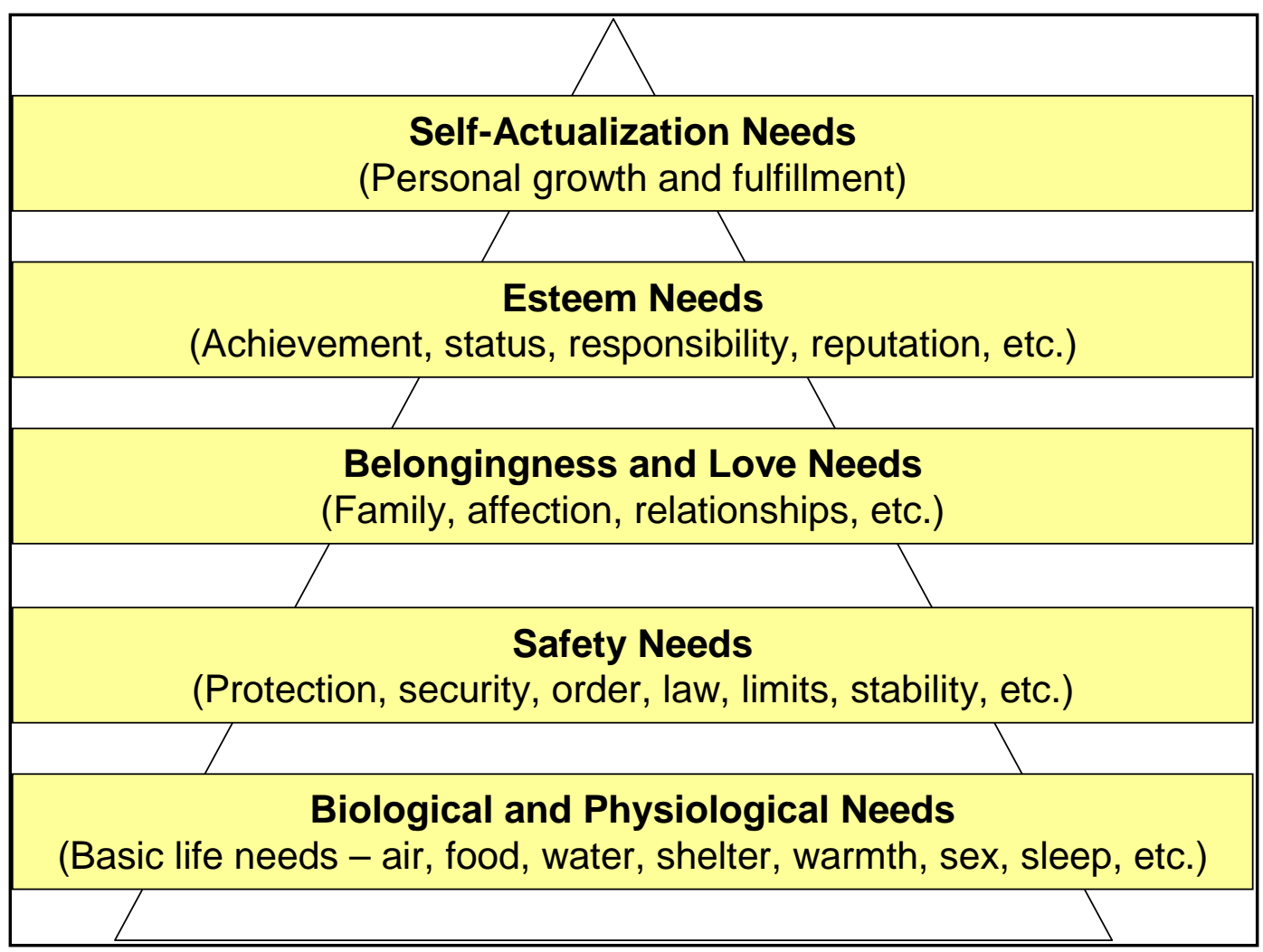

Figure 1. Maslow's hierarchy of needs.

1. Identity is the sense of self as a member of a group, distinct from and distinguished from other groups by values, beliefs, norms, roles, and culture. Many theorists see the need to cultivate group identities as part of humans' social nature. Related to the concept of identity is the concept of cultural security: the need for the recognition and honoring of one's language, traditions, and values. Identity and cultural security are factors in well-being and satisfaction in that they are seen to confer a core sense of definition and grounding. In circumstances where basic identity needs are threatened, dishonored, or violated, dissatisfaction and conflict are likely to develop. ${ }^{1}$

2. Freedom is the condition of having no physical, political, or civil restraints and having the capacity for choice.

3. Participation means being able to interact with others to influence social outcomes. Complex social structures pose greater challenges for participation. Theories of democracy recognize the critical role of participation in legitimizing group action and building group cohesion

1 John Burton, an imminent conflict resolution scholar has postulated that the need for "identity" is among the most fundamental definers of humanness and is the source of many of the world's deepseated and intractable conflicts when identity needs go unmet. See, for example, Burton (1990). 
(Delli Priscoli 2004). A 1976 United Nations conference on human settlements recommended that public participation should bean indispensable element of all planning strategies noting: "Meeting basic human needs and improving the quality of human life in human settlements requires critical choices in the allocation of scarce resources, the utilization of available resources, and the harnessing of new ones; this process cannot be effective without the active involvement of the people affected by such decisions." (United Nations 1976). Similarly, the 1992 UN Conference on Water and Environment in Dublin (United Nations 1992) developed the so-called "Dublin Principles” on water and sustainable development including the following:

Principle No. 2 - Water development and management should be based on a participatory approach, involving users, planners and policy-makers at all levels. The participatory approach involves raising awareness of the importance of water among policy-makers and the general public. It means that decisions are taken at the lowest appropriate level, with full public consultation and involvement of users in the planning and implementation of water projects.

4. Distributive justice is the perception of fairness in the allocation of resources. This concept has been most fully articulated by J ohn Rawls in his landmark bookA Theory of J ustice (1970). For a society to endure and avoid significant conflict there must be a general sense that allocation procedures are fair. At least three societal approaches are possible:

a. allocation based on equality (e.g., socialist systems)

b. allocation based on competition (e.g., capitalist systems)

c. allocations based on need (e.g., collectivist systems)

Society's systems of rules, norms and beliefs generally act to support one of these approaches more than another. Additionally, fairness is seen to have a process aspect as well as an outcome aspect. That is, society's rules prescribing how decisions about allocations are to be made are extremely important in legitimizing those decisions. Where procedural norms are violated, the allocation itself is judged to be unfair and social unrest and conflict are more likely (Deutsch 2000). 


\section{Social connectedness}

Related to the fundamental human needs described by Maslow as "belongingness" and by conflict theorists as "identity needs," social connectedness refers to the pattern of social networks within which individuals interact, which largely provides meaning and structure to life. A current term to focus this concept is "social capital," popularized by J ames Putnam in his book Bowling Alone (2000). Social networks are composed of horizontal associations that are generally focused at community and family levels of interaction and also of vertical associations that bridge across communities and levels of society. Networks can be among relatively homogeneous groups or among heterogeneous groups. The amount and diversity of such networks may have significant implications for the character of society, with those communities having primarily homogeneous networks being more provincial and closed, while communities having greater diversity of associations among heterogeneous groups are more cosmopolitan and open.

From the standpoint of quality of human life, either type of social connectedness may provide individual satisfaction; however, social capital theorists generally focus on the benefit to be gained by cultivating an array of diverse voluntary associations in communities to build "civic infrastructure" that can provide individuals with greater opportunities for connectedness, build reciprocity, improve communication and coordination, and strengthen intergroup relations. Studies suggest that communities and regions having such robust civic infrastructure are likely to be more economically and socially progressive and resilient than communities and regions where such patterns of connectedness are not present (Putnam 1993). The World Bank has established a "Social Capital Web site" (http:// www1.worldbank.org) noting that the cultivation of community social capital is an essential component of generating development and reducing poverty.

\section{Social vulnerability}

Social vulnerability refers to the capacity for being damaged or negatively affected by hazards or impacts. Vulnerability is associated with characteristics of the population - i.e., certain groups (the aged, the poor, minorities) may be more vulnerable than other parts of the population (Boruff et al. 2005; Cutter et al. 2000; Rygel et al. 2005; Heinz Center 
2000). Such groups may lack the resources and capacities to resist the hazard (as, for example, the inability to effectively mobilize opposition to a highway alignment or a waste facility siting) or to recover from the effects of a hazard (as, for example, poor people and communities may lack the financial resources to rebuild after a devastating flood).

Overlaying the spatial distribution of vulnerable populations with hazard zones associated with flooding or other potential disasters using Geographic Information System (GIS) technology produces as assessment of place vulnerability (see Cutter et al. 2000). Place vulnerability analysis offers a way of examining where vulnerable populations are in relation to hazardous areas and has great applicability for disaster management. For example, areas having greatest hazard potential and the greatest concentration of vulnerable populations would likely require different sorts of emergency preparedness and response strategies than low hazard - low vulnerability areas.

\section{Social vulnerability and Hurricane Katrina}

Hurricane Katrina struck the Louisiana, Mississippi, and Alabama coasts on August 29, 2005. The devastation of the hurricane and the flooding of the City of New Orleans produced by levee breaks from the hurricane created a catastrophe without precedent in the United States. As part of the comprehensive assessment of the performance of hurricane protection infrastructure undertaken by the Corps of Engineers through the Interagency Performance Evaluation Team (IPET), a team of nine social scientists was assembled to consider the socio-cultural effects of the disaster.

While carefully caveated to reflect the difficulties in gaining definitive answers in a chaotic situation, the researchers' conclusions, nevertheless, provide stark testimony to the social effects of a disaster on vulnerable populations:

"It is clear that Katrina and the flood represent catastrophic physical damages with potentially vast social, cultural and historic consequences. At all levels of social interaction it is possible to observe the potential for trauma. A few examples demonstrate this. At the interpersonal level, families and social networks have been disrupted perhaps permanently. The linking mechanisms between households 
and organizations, social support services, schools, health care and more have been severed in many cases and have been slow to repair. Faith in the system that was depended on for life-saving rescue has probably been undermined. Connections to large-scale institutions such as the school sector, the political process and the economic system have been dramatically altered.

Thus, at all levels it is possible to observe profound alterations. Perhaps what is most poignant comes from the neighborhood level though, where neighbors and organizations had labored valiantly to transform their areas and to enable Greater New Orleans to rise from its beleaguered social problems pre-Katrina. Those social processes and grass-roots efforts to improve local life chances have been abbreviated and perhaps irrevocably taken away. To understand disasters, it is necessary to examine the intersection between the built environment (e.g., levees, homes, business districts), the physical environment (wetlands, meteorological conditions, elevations) and the socio-cultural environment (the people). Disasters result from a misfit between these three key systems (Mileti 1999). To provide for an appropriate level of protection for the people, then, discussion must take into consideration the other two systems. Ultimately, what determines the line between acceptable and unacceptable risk reflects social, political and even economic contexts and realities. Any decision about levels of protection reflects these realities; what is key to understand from the perspective of this chapter is that the socio-cultural dimension is a critical component that cannot be divorced from engineered solutions" (IPET 2006; VII-4-94).

\section{Environmental justice}

Closely allied to the concept of social vulnerability is that of environmental justice (EJ ). Executive Order 12898, "Federal Actions to Address Environmental J ustice in Minority Populations and Low-Income Populations," mandates that each Federal agency "identify and address, as appropriate, disproportionately high and adverse human health or environmental effects of its programs, policies, and activities on minority 
populations and low-income populations." The EJ Executive Order was created to combat the fact that poor and minority groups often have been exposed to greater human health and safety risks than society at large and have borne more than their share of the negative effects of development. The EO directs Federal agencies to disclose the distribution of social and environmental effects on minority and poor populations and to ensure that such groups are afforded opportunities to fully participate in agency decision-making procedures. Various agencies such as EPA and Federal Highway Administration have developed extensive EJ Web sites and offer guidance and training in the conduct of EJ analyses. ${ }^{1}$

\section{Environmental justice in the Comprehensive Everglades Restoration Project $^{2}$}

As part of the Comprehensive Everglades Restoration Plan (CERP) the Corps, along with the prime state sponsor, South Florida Water Management District (SFWMD), has developed an Environmental and Economic Equity (EEE) Program Management Plan

(www.evergladesplan.org) (August 2001). The EEE Plan “...deals with the social, cultural, behavioral, historical and/ or economic subjects involved with CERP. The plan's purpose is to maximize the potential benefits both system-wide, and project-specific, resulting from CERP activities and to minimize any adverse social or economic impacts that may arise." The initial EEE plan is a five-year plan, with an estimated cost of $\$ 6$ million.

In December of 2002, the SFWMG and the Corps issued a joint memorandum setting forth guidelines for incorporating environmental justice issues in planning specific restoration projects. Among other things, it specifies that:

- In describing the "affected environment" the socio-economic environment will be described, including minority or low-income communities and their issues and concerns.

- Performance measures or criteria will be developed by an interdisciplinary team, in the early stages as goals and objectives are established for the project.

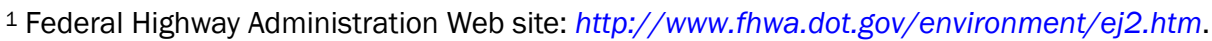

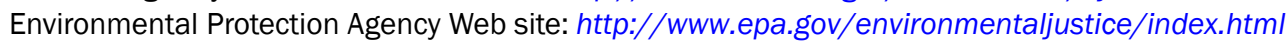

2 Excerpted from National Academy of Public Administration (2007).
} 
- In formulating and assessing alternative plans, most projects will use multiple criteria. There will, for example, be criteria for: biological measures (habitat, wetlands function); water hydrology; cost; systemwide restoration; project-specific restoration; and environmental justice and socio-economic well-being.

\section{Progress to date}

In an October 2005 report to Congress, the Assistant Secretary of the Army (Civil Works) reported progress on CERP implementation. The report points to four specific environmental justice accomplishments since 2001:

- Extensive efforts were undertaken to ensure the process is open to all audiences. A broad set of stakeholders has been identified. Examples of efforts undertaken include, town hall meetings to inform and engage the community in program decisions, one-on-one sessions to educate various communities about the importance of CERP, meetings in minority and "front porch" communities, multilingual newsletters and meetings, and discussions with business and commerce groups at which environmental justice was a highlighted issue.

- The Corps and SFWMD worked with EPA to develop an Environmental J ustice Collaborative Training Program. They partnered with EPA to provide training to project managers and involved community members.

- Development of an EJ "how to" training module, applied in the Corps planning process.

- Custom-made maps were developed using Census information and applying EPA's thresholds for interpreting the 2000 Census data. The maps show the locations of low-income and minority communities. They are available on the Web and, according to the report, have helped project managers, team members, and the public "see where projects and populations of concern intersect."

\section{Surveys of quality of life factors}

Social surveys of quality of life factors attempt to measure a region's wellbeing. To do so, the survey must move to a more specific operationalization of the broad concepts of well-being. Three survey approaches are discussed in the following paragraphs. The variables 
selected to measure well-being are closely related to, or derivable from, the theoretical concepts discussed in the previous section.

\section{European system of social indicators (EUSI)}

Funded by the European Commission, the focus of this research is to "develop a theoretically as well as methodologically well-grounded set of measurement dimensions and indicators to be used for a continuous monitoring of the quality of life and societies across Europe" (GESIS Web page). ${ }^{1}$ The concept of quality of life or well-being of individuals and communities is seen as a broader and more appropriate focus of concern for pluralistic, post-industrial societies than the single-dimension measure of societal wealth (Berger-Schmitt 2000; Noll 2004). The EUSI has measured quality of life along several dimensions:

1. Objective living conditions focused on standard of living, state of health, and working conditions.

2. Subjective assessments of well-being, satisfaction, and happiness.

3. Social cohesion focused on disparities, inequalities, and social exclusion, as well as social relations, ties, and inclusion.

4. Preservation of human and natural capital focused on people's skills, education, and health as well as the sustainability of natural resources.

\section{Economist intelligence unit's quality of life index (2005)}

As the author's note: 'It has long been accepted that material well-being, as measured by GDP per person, cannot alone explain the broader quality of life in a country. ${ }^{2}$ One strand of the literature has tried to adjust GDP by quantifying facets that are omitted by the GDP measurevarious nonmarket activities and social ills such as environmental pollution. But the approach has faced insurmountable difficulties in assigning monetary values to the various factors and intangibles that comprise a wider measurement of socio-economic well-being." 3 The economist, instead, focused on using regression analyses to examine the constituents of life satisfaction from surveys conducted in numerous

1 Web-site: http://www.gesis.org/en/social_monitoring/social_indicators/Data/EUSI/framework.htm

2 This statement refers to the so-called "paradox of happiness," which refers to the finding of numerous studies that in developed countries reported levels of happiness do not increase with income levels once a threshold level of income has been reached (Biswanger 2003; Easterlin 2001; Oswald 1997).

3 The authors' assertion that such difficulties are "insurmountable" is open to question. Much work is on-going to develop monetary proxies for many nonmarket variables (see, for example, Young 2005: pp.30 - 36). 
countries. The resulting regression analysis explained more than 80 percent of the variation in life satisfaction scores. The principle regression variables in the equation in order of explanatory power were: health, material well-being, political stability and security, family relations and community life, climate, job security, political freedom, and gender equality.

\section{New Zealand quality of life indicators}

New Zealand has routinely collected information on 56 key quality of life indicators in its metropolitan areas since 1999. ${ }^{1}$ The time-series data, often broken down by ethnicity, age, and sex, provide a broad perspective on social well-being in the country's cities. ${ }^{2}$

The 56 indicators are broken down into 11 categories:

1. population (demographics)

2. natural environment

3. knowledge and skills

4. built environment

5. economic standard of living

6. safety

7. economic development

8. social connectedness

9. housing

10. civil and political rights

11. health

\section{Civic indices}

Civic indices measure a community's social connectedness by focusing on a community's "civic infrastructure" - the formal and informal processes and networks that communities use to make decisions and solve problems. The development of civic indicators has been championed by the National Civic League (1999) (Hoagland 2005) through the development of its Civic Index procedure. The Civic Index is not a single index of definite

\footnotetext{
1 Web-site: $h$ ttp://www.bigcities.govt.nz/

2 It is interesting to note that a distinguished panel of social scientists proposed such a system for the United States in 1969 in Toward a Social Report (U.S. Department of Health, Education, and Welfare 1969) under the charge from the Secretary of Health, Education, and Welfare to "search for ways to improve the Nation's ability to chart its social progress."
} 
indicators. Rather it is a discursive process undertaken by communities to self-evaluate and assess the state of their civic infrastructure and to help focus on areas where capacity building is needed. The Civic Index focuses on 12 key themes of civic health and provides 363 example indicators that can be used to help focus on these themes. The Civic League points out that a viable and vital community must be evaluated on much more than its wealth. ${ }^{1}$ Figure 2 presents the 12 themes considered in the Civic Index.

1. Vision: Is there a shared community vision for the future?

2. Local Government: Is local government bringing together all sectors of the community for collaborative decision-making and joint action?

3. New Roles for Business: Is the business community actively involved in the community, partnering with government, non-profits, and citizens?

4. New Roles for Non-profits: Do non-profits collaborate with other non-profits, businesses, and government?

5. New Roles for Citizens: Are citizens engaged and actively involved in decision-making and solving problems in the community?

6. Diversity: Is diversity valued, with differences viewed as enhancing rather than hindering the community?

7. Consensus: Does the community attempt to resolve conflict and build consensus?

8. Sharing Information: Does the community have good communication avenues so that information is shared and readily available?

9. Crossing Jurisdictional Lines: Does the community work together with surrounding jurisdictions?

10. Learning from Experiences: Does the community honor the past, drawing upon the past to enhance the future?

11. Educating Citizens: Does every sector of the community (private and public) take responsibility for contributing to citizenship education?

12. Building Leadership: Is the public, private, non-profit, and grassroots community developing community leadership that is inclusive of the diversity of the community?

Hoagland 2005

Figure 2. Civic index key themes.

Other civic indices have focused on the ideal of sustainable communities as a goal and have promoted the development of indicators that portray the links among a community's economy, environment, and society (Hart 2005). The author of these indicators notes that focusing on any one aspect of community - economy, society, or environment - to the

1 "Too much and too long we seem to have surrendered community excellence and community values in the mere accumulation of material things. The Gross National Product (GNP) - if we should judge America by that - includes air pollution and advertising for cigarettes, and ambulances to clear our highways of carnage. It counts special locks for our doors and jails for those who break them. It counts the destruction of the redwoods and the loss of our natural wonders in chaotic sprawl...lt does not allow for the health of our families, the quality of their education, or the joy of their play...lt measures everything, in short, except that which makes life worthwhile. And it tells us everything about America except why we are proud that we are Americans." (Robert F. Kennedy address, University of Kansas, March 18, 1968; quoted in Hoagland 2005, pp. 2-3). 
exclusion of the other parts leads to piecemeal solutions and tends to force people to take sides on issues that should be addressed in an integrated fashion.

\section{Conclusions}

The purpose of the review of theoretical concepts, surveys, and studies was to identify what others have focused on when defining well-being. As the review shows, well-being is an ensemble concept composed of multiple dimensions. The review suggests that while economic factors are very important in characterizing well-being there are many more factors which come into play. In particular the distribution of resources; the character and richness of personal and community associations; the social vulnerability and resilience of individuals, groups, and communities; and the ability to participate in systems of governance are all elements that help define well-being. This constellation of well-being elements is illustrated in Figure 3. As the figure suggests, a water resources planning process that is exclusively or even essentially focused on maximizing "National Economic Development" is missing a huge range of important issues that will influence to what degree the water resources solutions that are developed will be judged as effective, acceptable, and fair. In large measure, such issues are the province of the Other Social Effects account. ${ }^{1}$

1 The current OSE account as described in Engineering Regulation (ER) 1105-2-100, Appendix D (USACE 2004) addresses many of the well-being concepts and elements that have been discussed in this section. Appendix A of this report arrays the concepts and variables discussed in this section and compares them to the OSE variables listed in the ER. 


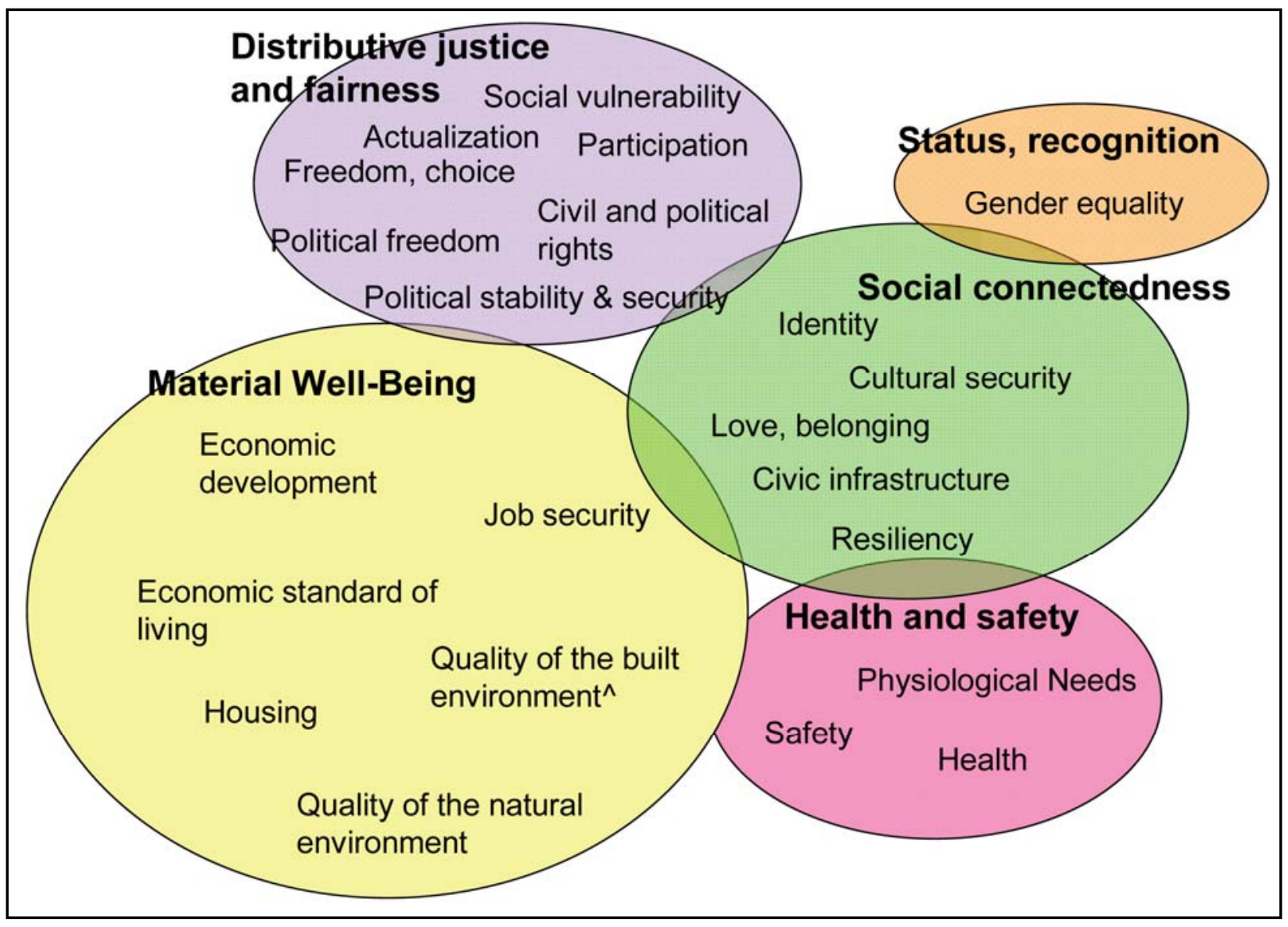

Figure 3. Constellation of well-being concerns. 


\section{The Decline of Interest in and Concern with the OSE Account}

\section{Overview}

Water resources development has always been about furthering broad social purposes including providing water supply to open the West, providing water transportation and harbors for commerce, controlling floods, and providing recreation and low-cost power. However, Congress and the Executive Branch have also spoken specifically on the role of social factors in the plan formulation, evaluation, and decision-making process since at least the 1936 Flood Control Act. "Section I of [the Act] specified circumstances for federal involvement in improvements for flood control: The federal government should improve or participate in the improvement of navigable waters or their tributaries, including the watersheds thereof, for flood control purposes if the benefits to whomsoever they accrue are in excess of estimated costs, and if the lives and social security of people are otherwise adversely affected' (NRC 1999)." However, after an initial flurry of activity in the 1970's interest in the OSE account has waned. This section traces a few of the causes for the decline in concern with the OSE account: water resources policy changes, the adoption of the P\&G, and the analytical framework for the conduct of OSE analysis itself. ${ }^{1}$

\section{Water Resources Development Act (WRDA) of 1986}

This landmark legislation fundamentally changed the water resources development "rules of the game" by instituting broad requirements for sharing the cost of water resources development between the federal government and cost-sharing project sponsors and also requiring cost sharing of feasibility studies between the federal government and local project sponsors. The intent of the legislation was to discipline the project development process by instituting "user pay" principles. While most

\footnotetext{
1 Appendix B traces the development of Federal water policy with specific focus on OSE parameters. As this short history shows, Congress has always taken a more expansive view of the importance and criticality of OSE (as well as Regional Economic Development), while the Executive Branch, principally in the guise of the Bureau of the Budget/OMB, has sought to move the consideration of OSE to the periphery of the decision-making process, concentrating instead on national economic development considerations.
} 
reviewers of the impact of WRDA 86 conclude that cost sharing has had this intended effect, it has also been widely concluded that WRDA 86 has had a number of unintended consequences, including:

- The scope of water resources problems and opportunities being considered by the Corps being more restricted to conform to the interest of the study cost-sharing partners (National Research Council 2004b); and

- The promotion of single-purpose projects, developed on a project-byproject, piecemeal basis and the reduction of interest in broader-scale, integrated water resources management approaches with more comprehensive solutions at regional or basin scales (National Research Council 2004a; National Research Council 1999). ${ }^{1}$

These effects of WRDA 86 on project development have led to a drive to focus on "essentials" in the planning process. Such essentials boil down to finding a cost share partner as quickly as possible and formulating an NED solution to water resources problems that is acceptable to the local sponsor. In such circumstances OSE concerns may not be viewed as essentials in the formulation or evaluation of alternatives. It is also possible that the emphasis on meeting the sponsor's interest may cloud the issue of whether and to what extent the national interest in water resources development may be better served by considering a broader range of alternatives at a regional or watershed scale of analysis, employing a full range of economic, environmental, and social factors to formulate and evaluate solutions.

\section{Principles and guidelines}

The Principles and Guidelines for Water and Related Land Resources Implementation Studies (P\&G), approved in 1983, provide the detailed analytic framework used by the Corps of Engineers to formulate and evaluate water resources solutions. The P\&G replaced the Principles and

\footnotetext{
1 LTG Robert Flowers, the Chief of Engineers summarized this point of view in his testimony before the Senate Committee on Environment and Public Works in 2002: "Right now, existing laws and policies drive us to single focus, geographically limited projects where we have sponsors sharing in the cost of the study. The current approach narrows our ability to look comprehensively and sets up inter-basin disputes. It also leads to projects that solve one problem but may inadvertently create others. Frequently we are choosing the economic solution over the environmental, when we can actually have both. I believe the future is to look at watersheds first; then design projects consistent with the more comprehensive approach." (Quoted in National Research Council, 2004a, p. 117.)
} 
Standards for Planning Water and Related Land Resources (P\&S) which were adopted in 1972. P\&G differs from the P\&S in several key ways:

- The P\&S framework stipulated two national objectives for water resources development - NED, and Environmental Quality (EQ) whereas P\&G has one national objective - NED.

- The P\&S framework included four accounts for use in developing water resources solutions - NED; EQ; Regional Economic Development (RED); and Social Well-Being (SWB). RED and SWB effects were to be displayed as appropriate in the consideration of planning alternatives. In the P\&G there are still essentially the same four accounts (the OSE account having replaced the SWB account); however, only the NED account must be displayed.

- The P\&S constituted legal guidance, whereas the P\&G is recommended guidance that has no legal force (National Research Council 1999).

- The P\&S was administered by the Water Resources Council, a cabinetlevel group chaired by the Secretary of the Interior, assisted by a professional water resources executive director and staff. The $P \& G$ is administered by the OMB, an executive budget agency.

Even though the P\&G is officially "recommended guidance" its influence on the Corps of Engineers project development and budgeting process is enormous. Essentially the drive of the entire project development process has been focused on finding the NED project. OMB has then used NED expressed as a project's benefit to cost ratio, or remaining benefits to remaining costs for ongoing construction projects - as the central determinant in selecting projects for inclusion in the President's Budget. ${ }^{1}$

The single objective focus of the P\&G has had the effect of pushing the other three accounts to the periphery. A variety of expert panels has concluded that such single-minded focus on NED is inappropriate for contemporary water resources development needs:

- "Calculations of NED are meant to include all environmental and social benefits and costs for which monetary values can be obtained. The monetary focus on NED, however, does not give adequate

1 The weight accorded to NED analysis accounting versus OSE factors can be roughly discerned by comparing the number of pages of guidance focused on NED (47 out of 49) compared to the number of pages devoted to the OSE account (2 out of 49) in Appendix D to ER 1105-2-100. This disparity calls to mind the example (quoted in Daneke and Delli Priscoli 1979) of the recipe for horse and rabbit stew: having added one horse and one rabbit to the stew, the stew still tastes of horse. 
consideration to unquantifiable environment and social values. Because of their nonmarket nature, environmental quality, ecosystem health, the existence of endangered species, and other social effects are not as easily quantified in monetary values. This limits formulation and acceptance of projects capable of striking a better balance between flood damage reduction or other water resources development and the environment." (Interagency Task Force on Flood Plain Management 1994).

- "P\&G...do not adequately reflect contemporary water resources planning principles and practices....Examples of specific revisions to the $P \& G$ which the committee recommends include: (1) movement away from the consideration of the National Economic Development (NED) account as the most important concern. Today, ecological and social considerations are often of great importance in project planning and should not necessarily be considered secondary to the maximization of economic benefits." (National Research Council 1999).

\section{Failure of social assessment to deliver useful results}

In addition to the structural inhibitors of WRDA 86 and the P\&G previously discussed, it must also be acknowledged that often social analyses offered little of value to the overall planning process. This view was succinctly expressed by the then Deputy Assistant Secretary of the Army for Civil Works in 1979:

"I believe it was the nonoperational definition of social wellbeing, as well as the very tenuous relationship between social well-being and project formulation that caused social well-being to be dropped as an objective. The wisdom of this decision is confirmed when we review the entries in the social well-being account in the typical report.

Social well-being impacts associated with a project consist mostly of speculations on what would appear to be carefully chosen components which serve in some weak way to promote the project. Thus, I read about how dredging a harbor serves to reduce crime, raise educational levels, and remove local "despair," but nothing about how the project might increase traffic congestion, degrade air quality, or cause the next port up or down the coast to slip into recession. I do not believe that the reader is swayed one 
way or another by such obviously self-serving analyses.

Until a more systematic and balanced analysis is presented, these kinds of social well-being impacts will providelittle more than added bulk to the project report." (Edward Dickey 1979, quoted in Galloway 1987)

There are several implications of this comment for the current effort to re-energize the OSE account. First, social factors information must be linked to the planning process in meaningful ways - i.e., the issues being considered should have some relationship to the plans under development. Second, the information needs to be comprehensive in scope - not selectively presented. Finally, it is also the opinion that in order for a truly reenergized OSE framework to emerge, practitioners must adopt a different role - moving from an "assessment model" to an "action research" model. This idea is presented in Chapter 5. 


\section{Uses of Social Factors Information by Other Agencies}

While interest in social well-being in Corps planning has languished over the past two decades, other agencies have found that information on social factors and well-being can be contribute substantially to appropriate decision-making. This section briefly reviews the experience of several government agencies, plus that of the World Bank, and the European Union with the use of social information.

\section{National Oceanographic and Atmospheric Administration (NOAA), Coastal Services Center}

The Coastal Service Center within NOAA has established a Human Dimensions Program to "provide products and services that foster recognition, understanding, and consideration of the social, cultural, and economic aspects of managing natural resources along the nation's coasts" (Human Dimensions Web site: http:// www.csc.noaa.gov/cms/ human_dimensions/focus_socialas.html). The program undertakes social and economic assessments and needs assessments to support coastal restoration projects and provides training and informational materials for NOAA natural resources managers on the uses of social science in coastal management. The center has explored the concept of social vulnerability of coastal residents and has worked with experts on the use of the social vulnerability index (http:// www.csc.noaa.gov/ rvat/ societalEdd.html), and community resiliency index to examine potential risks to communities and vulnerable populations from coastal storms and hurricanes. The Human Dimensions Program is also launching an interagency human dimensions Web portal - www.hd.gov - to serve as an on-line information resource on the human dimensions of natural resources management and to foster a community of practice in the human dimensions area. Twelve Federal agencies have expressed interest in participating in the portal.

\section{World Bank}

The mission of the World Bank is the reduction of poverty and attainment of equitable sustainable development. The Bank has recognized that social factors are critical to the attainment of these objectives, and a Social 
Development Department has been formed to work to increase the social capacities and assets of recipients of World Bank projects. The Social Development Department has four focus areas: community development and social capital formation, social analysis, participation and civic engagement, and conflict prevention. The Bank has a comprehensive Web site on social development ${ }^{1}$ and has developed an informative "Social Analysis Sourcebook," which provides useful information on the application of social analysis and assessment to further Bank development objectives. The Department has also developed an on-line training course in social analysis for development specialists.

\section{Forest Service}

The Forest Service uses human dimensions information to help understand the interface between forest management activities and local and regional communities. Topics that have been explored include the human dimensions of fire management policies, the community impacts of land management strategies, and climate change implications. The Forest Service work conducts regional and smaller assessments to assist in the development of forest management plans, and social assessments are part of the overall process. The Forest Service has put together a comprehensive guide for conducting social assessments: A Human Dimensions Framework: Guidelines for Conducting Social Assessments (http://www.srs.fs.usda.gov/pubs/gtr/gtr_srs065.pdf).

\section{Natural Resource Conservation Service (NRCS)}

The NRCS has a social science team whose mission is to discover how social and economic aspects of human behavior can be applied to natural resource conservation programs, policies, and activities. The team maintains a social science Web site, http:/ / www.ssi.nrcs.usda.gov, which provides information on the program and publications produced. As a water agency, the NRCS also uses the P\&G as a basis for its water-related planning activities. OSE analysis has been used to justify the reduction in cost-sharing requirements for poor communities (Clearfield 2007). Additionally, the social science team has developed a number of interactive Web sites to assist planners in the conduct of agency work. One, the participation estimator, provides an estimate of the likelihood that a person will adopt new innovations in farming and watershed

\footnotetext{
1 World Bank Social Development Department Web address: http://web.worldbank.org/
} 
management based on a variety of personal and social variables. Another program uses social capital theory to estimate the social connectedness and level of trust in a community. This program is useful as a way of helping planners form appropriate strategies for interacting with communities, building trust within communities, and working with communities on NRCS projects. These programs are found at http://ssiapps.sc.egov.usda.gov/ SocialSciences/default.aspx.

\section{Tennessee Valley Authority (TVA)}

The Tennessee Valley Authority (TVA) was formed in 1933 and was charged by Congress with improving navigation and controlling floods for the general purpose of fostering the physical, economic, and social development of the Tennessee Valley region. TVA's mission is a good illustration of the use of economic development for purposes of the social improvement of a region. TVA has devoted considerable attention to documenting, measuring, and in some cases, monetizing effects associated with alternate transportation investments that are not captured in NED cost benefit procedures. The intent of such analysis is to provide additional perspective on decisions about potential new investments for navigation structures within the Tennessee Valley that may not have NED justification. The researchers at TVA point out that these navigation structures mean more to the valley than just the shipper savings that are being achieved, and they are critical of the NED-centric focus of current P\&G procedures (Bray 2006). They point out that other evaluation paradigms for transportation investments that are used by states are more multiobjective in focus. The additional factors that are introduced into the analyses include air pollution, accidents and death, road damage, recycling issues, noise, and greenhouse gas emissions. TVA uses a model known as STEAM (Surface Transportation Efficiency Analysis Model) (http:// www.fhwa.dot.gov/ steam) to portray the benefits and costs associated with alternate transportation investments.

\section{European Union}

The European Union (EU) has initiated a broad program of research and development to apply scientific knowledge for the assessment of flood risk leading toward an integrated European methodology for flood risk analysis and management. The research program is known as FLOODsite (www.floodsite.net) and has three key objectives: to improve understanding of the primary drivers of flood risk, to improve models and 
techniques for analysis of flood defense systems, and to evaluate the social consequences of flood events in order to improve preparedness, social resilience, risk communication and social and economic evaluation procedures and models. 


\section{Social Effects Information in the Collaborative Planning Paradigm}

A number of factors may be moving the Corps in the direction of broader, more collaborative, and more systems-oriented approaches to water resources planning in which there will be a role for a reinvigorated and robust OSE account. ${ }^{1}$ This section considers how OSE information should be used in the emerging collaborative planning framework (also termed the four-account framework to stress the importance of all accounts), discusses the role of the OSE practitioner, and presents several challenges in the use of OSE information that must be recognized and addressed.

\section{OSE information as a communication process}

What role should OSE information play in a collaborative planning framework? First and foremost OSE information should be used to enhance the process of communication among those interested and affected by water resources issues - in short, those who need to collaborate about the issues of concern. OSE information should be developed and used in the planning process as part of a "consensusforming" endeavor (Lord 1986; Dunning 1985) to help assist parties involved to understand the situation and issues from perspectives other than their own and to develop a deeper understanding of the views, positions, and underlying interests of those involved. The intent of this communication process is that stakeholders come to a deeper understanding of others' views as well as their own and that opportunities for shared interests and greater collaboration may be discovered, as well as differences and choices crystallized. ${ }^{2}$

This process of using information to assist communication in this manner has been described as creating the ideal speech situation (Habermas 1979; 1984). In this formulation, a robust public sphere and rationality of action proceeds from clarifying and engendering dialogue among all segments of society to foster the understanding of effects, trade-offs, and choices.

${ }^{1}$ Appendix $\mathrm{C}$ discusses the factors that are moving the Corps in the direction of collaborative planning and also considers a number of inhibitors of collaborative planning.

2 This crucial communication process is intended to help inform the analytic process of formulating, evaluating, and ultimately selecting a recommended plan. In this process there are national interests and policies represented in planning guidance that must be adhered to as well. 
No set "checklist" or formulaic approach for OSE factors can or should be supplied when considering social effects. The OSE analysis should be a process of exploration that is heavily influenced by the issues and concerns of stakeholders. However, it is likely that stakeholder concerns and issues will be grounded in the well-being concepts that have been reviewed in Chapter 2. The questions noted in Figure 4 are illustrative of the kinds of issues that the OSE analysis should be addressing.

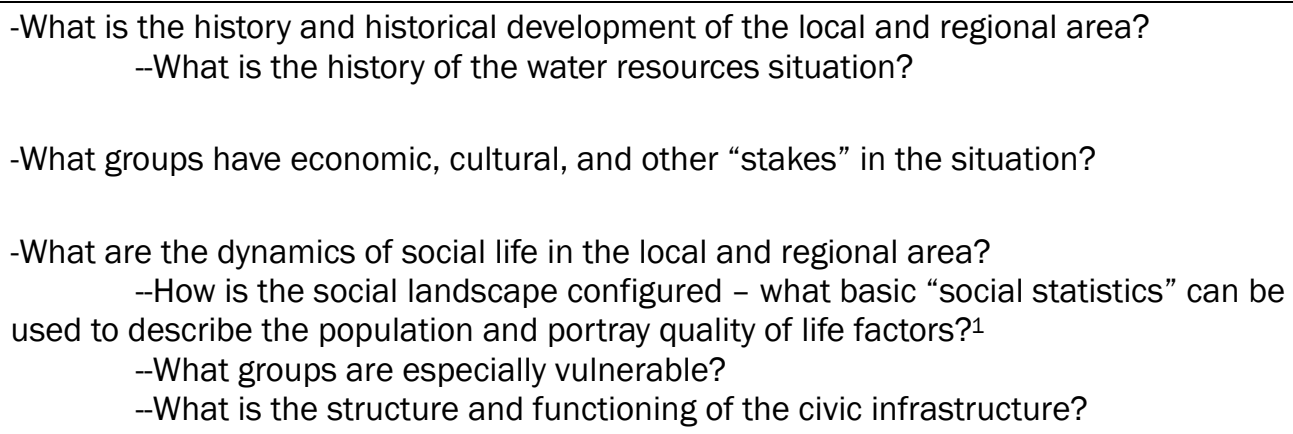

-How are social life and quality of life factors likely to change in the absence of a solution to the water resources issue? How are vulnerable populations likely to be affected? How are social connectedness, social capital/social resiliency, and risks to human health and safety likely to be affected?

-What are issues of concern in the solutions being offered for solving the water resources issue?

--How do stakeholders view the issues?

--What preferences do stakeholders have for addressing the water resources situation? What interests and values appear to be advanced with the particular suggestions being made by stakeholders?

--What appear to be intersections of interests? What are clear differences in interests or values among stakeholders?

- How are social life and quality of life factors likely to be affected by potential ways of addressing the water resources situation? How are vulnerable populations likely to be affected? How are social connectedness, social capital/social resiliency, and risks to human health and safety likely to be affected?

1 There are a number of guides to the conduct of "social profiles" to help describe the social structure and functioning of communities (Flynn and Schmidt 1977; Sanders 1960; University of Illinois 2006; Guseman and Dietrich 1978). Additionally, a descriptive model of social organization is being developed by the Human Ecosystems Study Group (http://www.webpages.uidaho.edu/ gmachlis/principal.html).

Figure 4. Some key OSE questions of concern.

Instrumentally such social effects information should be used to assist in several key planning tasks: 
1. Forming planning objectives. Planning objectives are the distillation of a process of identifying problems, needs, and opportunities. In this process, information about who is affected and how they see the situation is critical. It is particularly important that those who may be most vulnerable to risks be included in the process (Willeke 1974; Creighton 1982).

2. Forming and evaluating alternatives. Alternatives need to address social issues of concern, and where possible and feasible stakeholders should actively participate in the design of alternatives. At the very least, alternatives need to be formed with the expectation that they will be evaluated against social preferences of diverse stakeholders. Communicating the socioeconomic implications of alternatives, helping stakeholders to understand them, and explore the consequences of the alternatives on their situations and interests. Once again there should bea special responsibility to ensure that those stakeholders most vulnerable or at risk are afforded the opportunity - even provided special assistance - to participate in the exploration of alternatives. Another aspect of this overall facilitation of a communication process may also be to help ensure that those within the agency clearly understand the concerns, preferences, and issues raised by stakeholders.

3. Resolving conflicts. While not exclusively the province of the OSE practitioner, nevertheless the social analysis should help clarify issues and interests of stakeholders and should form the foundation for collaborative problem-solving about finding appropriate and acceptable solutions (Creighton et al. 1998).

\section{OSE in the new planning paradigm}

How might an expanded and reinvigorated OSE process look in the emerging collaborative planning framework? Table 1 compares and contrasts the role of OSE information in the collaborative planning framework (four-account planning framework, p. 18) as described in this report with the role that OSE analysis has typically played in the current planning framework. As can be seen, the OSE information is much more integrated into the planning process in the collaborative planning framework. 
Table 1. A Comparison of the role of OSE information in the current planning framework with the four-account planning framework.

\begin{tabular}{|c|c|c|c|c|}
\hline Planning step & $\begin{array}{l}\text { Current planning } \\
\text { framework }\end{array}$ & $\begin{array}{l}\text { Role of OSE/ } \\
\text { social information } \\
\text { in current } \\
\text { framework }\end{array}$ & $\begin{array}{l}\text { Four-Account planning } \\
\text { framework }\end{array}$ & $\begin{array}{l}\text { Role of OSE/ social } \\
\text { information in four- } \\
\text { account framework }\end{array}$ \\
\hline $\begin{array}{l}\text { Define and bound } \\
\text { the problem } \\
\text { * Opportunities } \\
\text { * Constraints } \\
\text { * Planning } \\
\text { Objectives }\end{array}$ & $\begin{array}{l}\text { Current paradigm } \\
\text { defines problems } \\
\text { narrowly, according to } \\
\text { specified authorities. } \\
\text { Projects are largely } \\
\text { single purpose. } \\
\text { Problems, constraints, } \\
\text { and planning objectives } \\
\text { are defined by } \\
\text { Sponsor/Corps }\end{array}$ & $\begin{array}{l}\text { Role may include } \\
\text { conducting } \\
\text { scoping } \\
\text { workshops, } \\
\text { generally as part } \\
\text { of the EIS process }\end{array}$ & $\begin{array}{l}\text { Four-account framework } \\
\text { defines problems more } \\
\text { broadly and focuses on } \\
\text { the full range of water } \\
\text { resources problems that } \\
\text { are beyond traditional } \\
\text { authorities. } \\
\text { Multipurpose/ } \\
\text { multiagency } \\
\text { involvement }\end{array}$ & $\begin{array}{l}\text { Role includes } \\
\text { identification and analysis } \\
\text { of social conditions and } \\
\text { stakeholder identification } \\
\text { and analysis. "Consensus- } \\
\text { forming activities" help } \\
\text { build common definitions } \\
\text { of problems, opportunities, } \\
\text { and constraints, and help } \\
\text { determine planning } \\
\text { objectives }\end{array}$ \\
\hline $\begin{array}{l}\text { Inventory and } \\
\text { forecast } \\
\text { conditions }\end{array}$ & $\begin{array}{l}\text { Current paradigm } \\
\text { develops most likely } \\
\text { future without-project } \\
\text { condition, based on } \\
\text { forecasts and models }\end{array}$ & $\begin{array}{l}\text { Role is generally } \\
\text { limited to } \\
\text { population and } \\
\text { employment } \\
\text { forecasts }\end{array}$ & $\begin{array}{l}\text { Engages stakeholders in } \\
\text { discussions about the } \\
\text { future to create either } \\
\text { "shared vision" of future } \\
\text { without- project } \\
\text { conditions or potential } \\
\text { multiple without- project } \\
\text { conditions }\end{array}$ & $\begin{array}{l}\text { Portrays social effects in } \\
\text { future without-project } \\
\text { conditions - based on } \\
\text { models, forecasts, and } \\
\text { expert opinions - to help } \\
\text { stakeholders fully } \\
\text { participate in the shared } \\
\text { visioning process }\end{array}$ \\
\hline $\begin{array}{l}\text { Formulate } \\
\text { alternatives: } \\
\text { management } \\
\text { measures }\end{array}$ & $\begin{array}{l}\text { Largely in-house } \\
\text { technical process links } \\
\text { management measures } \\
\text { to planning objectives. } \\
\text { Optimizes the NED } \\
\text { objective, except for } \\
\text { combined plans }\end{array}$ & $\begin{array}{l}\text { Generally } \\
\text { presents broad } \\
\text { socio- economic } \\
\text { information as } \\
\text { part of the EIS } \\
\text { process; does not } \\
\text { include } \\
\text { formulating } \\
\text { alternatives }\end{array}$ & $\begin{array}{l}\text { Links management } \\
\text { measures to planning } \\
\text { objectives, } \\
\text { unconstrained by NED } \\
\text { or agency authorities, in } \\
\text { cooperation with full } \\
\text { range of stakeholders } \\
\text { and participating } \\
\text { agencies }\end{array}$ & $\begin{array}{l}\text { Actively involves } \\
\text { stakeholders in } \\
\text { development of } \\
\text { alternatives that address } \\
\text { social issues and } \\
\text { concerns. Uses conflict } \\
\text { analysis tools to help } \\
\text { identify interests that need } \\
\text { to be addressed in } \\
\text { alternatives }\end{array}$ \\
\hline $\begin{array}{l}\text { Evaluate and } \\
\text { compare } \\
\text { alternatives: } \\
\text { Characterization } \\
\text { of effects }\end{array}$ & $\begin{array}{l}\text { Alternatives are } \\
\text { evaluated against the } \\
\text { objectives and rated on } \\
\text { completeness, } \\
\text { effectiveness, efficiency, } \\
\text { and acceptability where } \\
\text { the dominant evaluation } \\
\text { is NED }\end{array}$ & As above & $\begin{array}{l}\text { Alternatives are rated } \\
\text { on completeness, } \\
\text { effectiveness, efficiency, } \\
\text { and acceptability }\end{array}$ & $\begin{array}{l}\text { Social effects of } \\
\text { alternatives are disclosed } \\
\text { as part of acceptability } \\
\text { review in an open process } \\
\text { with stakeholders. Conflict } \\
\text { resolution processes help } \\
\text { build forums for } \\
\text { discussing issues and } \\
\text { negotiating alternatives }\end{array}$ \\
\hline $\begin{array}{l}\text { Select } \\
\text { recommended } \\
\text { plan }\end{array}$ & $\begin{array}{l}\text { Selection is made of } \\
\text { NED plan unless } \\
\text { exception is granted by } \\
\text { ASA }(C W)\end{array}$ & Confined to EIS & $\begin{array}{l}\text { Plan is selected on a } \\
\text { broader array of factors } \\
\text { including NED and } \\
\text { acceptability. Plan may } \\
\text { not lead to a Corps } \\
\text { project in the traditional } \\
\text { sense, but may be a } \\
\text { watershed management } \\
\text { plan }\end{array}$ & $\begin{array}{l}\text { Continues as above, with } \\
\text { emphasis on conflict } \\
\text { resolution analysis and } \\
\text { actions to help arrive at a } \\
\text { final acceptable plan }\end{array}$ \\
\hline
\end{tabular}




\section{Role of OSE practitioner}

For OSE information to be meaningful to the four-account planning framework, those developing the information must have a self-conscious orientation about their role in the planning process as that of "action researcher" versus that of "assessor." The philosophy and approach of action research was first developed by Kurt Lewin in the 1940's (Lewin 1948). Action research is described as "comparative research on the conditions and effects of various forms of social action and research leading to social action." The point of view of the researcher is not that of outside, disinterested observer, but one of activist interested in change: "It commences with an interest in the problem of a group, a community, or an organization. [Action research's] purpose is to assist people in extending their understanding of their situation and, thus, resolving problems that confront them" (Stringer 1999). This role stands in contrast to the traditional "scientific" model of the disinterested researcher, dispassionately observing and taking pains not to interfere with or "contaminate" the "experiment." Planning is a social undertaking, not a laboratory experiment, and the action research model uses the tools of science - careful observation and analysis - to help guide action and to intentionally modify the situation.

Action research works through three basic phases: ${ }^{1}$

- Look: build a picture and gather information

- Think: interpret and explain

- Act: resolve issues and problems

Within the context of the collaborative planning framework these phases would be oriented to the following iterative tasks:

- Identifying potential social well-being issues associated with the current situation and the future without condition. Discovering what stakeholders think about the water resources situation and what ideas they have about ways that it should be addressed. (Look phase).

- Reporting on how social well-being and quality of life issues may change in the future under the conditions brought about by the various

\footnotetext{
1 The similarity of this formulation to the "Scan, Focus, Act" nomenclature employed by the Corps of Engineers cadre of facilitators associated with the now-defunct "Fusion Center" is striking and not coincidental.
} 
alternatives being discussed and developed. Helping stakeholders understand and explore these implications. (Think phase).

- Applying interest-based problem solving to address acceptability issues associated with options and helping parties with proposals for mitigating unacceptable parts of plans. (Act phase).

Rather than advocating any particular outcome, the OSE practitioner would be an advocate for communication and disclosure and would use the principles of science - careful observation and accurate description to work for improved communication and understanding among stakeholders.

\section{Challenges in the use of OSE information}

While social effects information is central to the water resources planning process, there are a number of key challenges that complicate the use of OSE in plan formulation and evaluation. These challenges are briefly reviewed in the following paragraphs.

A primary issue is that of measuring and trading off social effects. For example, plan A has the likelihood of increasing community resilience. However, some vulnerable groups are left unprotected. Plan B may provide an acceptable level of protection for all, but may have little positive effect on the community's resiliency. Marginal economic analysis, by monetizing key economic impacts, provides an elegant way of addressing trade-offs of economic issues. However, many effects do not lend themselves to monetization, and the issue of how to deal with "incommensurables" that cannot be easily or clearly monetized is difficult. ${ }^{1}$ What is abundantly clear, however, is that adopting an implicit policy of "if you can't count it, it doesn't count" and ignoring important effects that are difficult to quantify, monetize, and trade-off in the planning process is unacceptable and can have tragic consequences if risks and vulnerabilities are not adequately addressed. As Stakhiv (1986) has noted, social effects information should come into play early in the

\footnotetext{
1 It may in fact be possible to monetize some types of social effects and move them into benefit cost procedures. For example, research was undertaken in the 1980's to develop a trauma benefits index to translate psychological trauma associated with having undergone a devastating flood experience into monetary damages using an medically vetted index and Veterans Administration payment scale (Allee et al. 1985). Another methodology that has some promise is the use of contingent valuation survey techniques to produce estimates of willingness to pay to accept or avoid certain risks and effects that are otherwise difficult to monetize through market procedures (Arrow et al. 1993 http://www.darrp.noaa.gov/library/pdf/cvblue.pdf); Young 2005).
} 
planning process to help identify planning objectives and screen out potential alternatives that do not meet local social acceptability criteria. For the remaining set of alternatives, the range of effects and key choices must be communicated to decision-makers. As has been noted, it is the responsibility of decision-makers to convert and weigh the different classes of effects and make judgments regarding incommensurables (Haimes 1987). Or, as was eloquently put by a political theorist, "Politics is the authoritative allocation of value" (Easton 1953).

It is to be hoped that advances will be made in measurement and modeling of social well-being factors and concerns so that a clearer understanding of how such factors might be affected by planning choices can be achieved. In this regard the development of trade-off analysis procedures and display techniques can be quite useful (Yoe 2002). Additionally, the development of shared-vision models shows great promise. In this approach, stakeholders actively participate with experts to define and measure social well-being concerns in multifaceted systems models. Stakeholders participate in running the models and evaluating choices based on the effects on key variables of concern predicted by the model. ${ }^{1}$

\footnotetext{
1 The Corps of Engineers Institute for Water Resources has pioneered in the development of shared

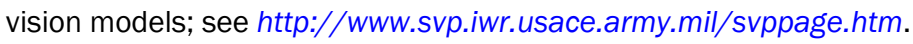




\section{Conclusions and the Way Ahead}

This report has shown that there is a large body of thought suggesting that a broad, multidimensional conception of well-being better reflects the concerns of complex, prosperous, pluralistic societies than does a singledimension focus on economic growth. It was also noted that even where economic growth must be the primary consideration, as is the case with economic development initiatives in less developed societies, a concern for social well-being factors is seen as vital to achieving acceptance and integration of economic development initiatives into the society in productive ways. A new emphasis on collaborative planning embodied in EC 1105-2-409 may move the Corps toward the development of water resources plans that are more in line with this broader conception of wellbeing.

If OSE analysis is to fulfill its promise in helping to achieve such an outcome, a number of supporting actions will be necessary. First, training of Corps personnel in OSE theory and methods will be necessary. As presented in this report, such training should stress the use of social information to enhance the process of communication among stakeholders about issues of concern. Additionally, the training should provide a model of the role of the OSE practitioner that is based on action research concepts. Finally, the training will need to confront a mindset created by the long dominance of NED analysis and carefully work through issues and skepticism of those socialized into the post-WRDA 86 planning paradigm.

Establishing a center of expertise (CX) within the Corps planning community to take the lead in advancing OSE knowledge and practice is also necessary. In particular, there is a need for the development of a handbook on OSE methods, and for models that can measure and display well-being factors in relation to other water resources parameters and assist in discussions about trade-offs. In this respect, the recent work on shared vision models in the water resources community is provocative and encouraging. Additionally, the Corps, working through the CX, needs to continue to reengage with the body of practice in human dimensions, social factors, and quality of life work that is located in other Federal agencies, the World Bank, the European Union, other organizations, and 
academia. Sponsorship of a joint workshop or conference with such agencies and groups on the use of social information in collaborative planning would be an appropriate focusing action. 


\section{References}

Allee, D., L. G. Antle, A. Motz, B. Osgood, C. Simpkins, and A. VanDerslice. 1985. Human costs assessment - The impacts of flooding and nonstructural solutions - Tug Fork Valley, West Virginia and Kentucky. IWR Report 85-R-4. Fort Belvoir, VA: U.S. Army Corps of Engineers, Institute for Water Resources.

Arrow, K., R. Solow, P. Portney, E. Leamer, R. Radner, and H. Schuman. 1993. Report on the NOAA Panel on Contingent Valuation. Washington, DC: NOAA.

Berger-Schmitt, R. 2000. Social cohesion as an aspect of the quality of societies: Concept and measurement. EU Working Paper No. 14. Mannheim, GE: Center for Survey Research and Methodology (ZUMA).

Biswanger, M. 2003. Why does income grouth fail to make us happier? - Treadmills behind the paradox of happiness. Discussion Paper 2003-W01. Switzerland: Solothurn University of Applied Sciences.

Boruff, B., C. Emrich, and S. Cutter. 2005. Erosion hazard vulnerability of U.S. coastal counties. J ournal of Coastal Research. 21(5).

Bray, L. 2006. Personal communication, December 22. Tennessee Valley Authority.

Burgess, G., and H. Burgess. 2005. Unmet human needs. The Beyond Intractability Knowledge Base Project. Boulder, CO: University of Colorado. (www.beyondintractabillity.org).

Burton, J . 1990. Conflict resolution and prevention. New York: Saint Martin’s Press.

Caulfield, H. 2000. Early federal guidelines for water resources evaluation. Water Resources Update, March.

Clearfield, F. 2007. Personal communication, J anuary 3. National Resources Conservation Service.

Creighton, J . 1982. Identifying publics: Staff identification techniques. J . Creighton, J . Delli Priscoli, and C. M. Dunning, ed., Public involvement techniques: A reader of ten years of experience at the Institute for Water Resources. IWR Report 82R-1. Fort Belvoir, VA: U.S. Army Corps of Engineers, Institute for Water Resources.

Creighton, J., T. Wetherall, and J . Delli Priscoli. 1998. Overview of alternative dispute resolution (ADR). J . Creighton, J . Delli Priscoli, C. M. Dunning, and D. Ayres, ed., Public involvement and dispute resolution: A reader on the second decade of experience at the Institute for Water Resources. IWR Report 98-R-5. Fort Belvoir, VA: U.S. Army Corps of Engineers, Institute for Water Resources.

Cutter, S., J . Mitchell, and M. Scott. 2000. Revealing the vulnerability of people and places: A case study of Georgetown County, South Carolina. Annals of the Association of American Geographers 90(4): 713-737. 
Danake, G., and J . Delli Priscoli. 1979. Social assessment and resource policy. Natural Resources J ournal. 19: 359- 375.

Delli Priscoli, J . 2004. What is public participation in water resources management and why is it important? Water International 29(2): J une 221- 227.

Department of the Army. 2006. U.S. Army Corps of Engineers Five Year Development Plan: Fiscal Year 2007- Fiscal Year 2011. Washington, DC.

Deutsch, M. 2000. J ustice and conflict. In Handbook of conflict resolution: Theory and practice. M. Deutsch and P. Coleman, ed., San Francisco: J ossey-Bass.

Dunning, C. M. 1985. Applying sociology in natural resources management agencies: Examples from the Army Corps of Engineers. Sociological Practice 5(2): 193208.

Durden, S., and L. Almodovar. 2006. Review of guidance and procedures for regional economic development and other social effects. IWR White Paper, August 2006. Fort Belvoir, VA: U.S. Army Corps of Engineers, Institute for Water Resources.

Easterlin, R. 2001. Income and happiness: Towards a unified theory. Economic J ournal 111: 465- 484 .

Easton, D. 1953. The political system. New York: Alfred Knopf.

Economist Intelligence Unit. 2005. Quality of life index. The World in 2005.

Flynn, C., and R. Schmidt. 1977. Sources of information for social profiling. IWR Report 77-9. Fort Belvoir, VA: U.S. Army Corps of Engineers, Institute for Water Resources.

Galloway, G. 1987. The role of social sciences in putting "people" into Federal water resources project planning and evaluation. In D. Baumann and Y. Haimes, ed., The role of social and behavioral sciences in water resources planning and management. New York: American Society of Civil Engineers.

Guseman, P., and K. Dietrich. 1978. Profile and measurement of social well-being indicators for use in the evaluation of water and related land management planning. Miscellaneous Paper Y-78-2. Vicksburg, MS: U.S. Army Engineer Waterways Experiment Station.

Habermas, J . 1979. Legitimation crisis. Boston: Beacon Press.

1984. The theory of communicative action, Vol I. Boston: Beacon Press.

Haimes, Y. 1987. Alternatives to the precommensuration of costs, benefits, risks, and time. In D. Baumann and Y. Haimes, ed., The role of social and behavioral sciences in water resources planning and management. New York: American Society of Civil Engineers.

Hart, M. 2005. Sustainable measures.

(http://www.sustainablemeasures.com/index.html). 
Headquarters, U.S. Army Corps of Engineers. 1999. Policy Guidance Letter \#61 Application of Watershed Perspective to Corps of Engineers Civil Works Programs and Activities. CECW-AA. Washington, DC: 27J anuary.

. 2000. Water resources planning. Engineering Regulation (ER) 1105-2100. Washington, DC.

. 2001. A national dialogue about America's water resources challenges for the 21st century: National report on identified water resources challenges and water challenge areas. Washington, DC.

. 2004. Department of the Army Corps of Engineers Civil Works Strategic Plan, Fiscal Year 2004 - Fiscal Year 2009. Washington, DC. March.

. 2005. Planning in a collaborative environment. Engineering Circular 1105-2-409. Washington, DC.

. 2006. Draft interim implementation procedures. Engineering Circular (EC) 1105-2-409. Washington, DC.

H. J ohn Heinz III Center for Science, Economics and the Environment. 2000. The hidden costs of coastal hazards: Implications for risk assessment and mitigation. Washington, DC: Island Press.

Hoagland, D. 2005. Civic indicators handbook. Denver, CO: National Civic League.

Interagency Performance Evaluation Task Force. 2006. Performance Evaluation of the New Orleans and Southeast Louisiana Hurricane Protection System - Draft Final Report. Washington, DC: U.S. Army Corps of Engineers.

Interagency Task Force on Floodplain Management. 1994. Blueprint for change. Sharing the challenge: Floodplain management into the 21st century. Washington, DC: National Technical Information Service.

Lewin, K. 1948. Resolving social conflicts: Selected papers on group dynamics. New York: Harper and Row.

Lord, W. 1986. Evolutionary perspective on social values. In W. Viessman, J r., and K. Schilling, ed., Social and environmental objectives in water resources planning and management. New York: American Society of Civil Engineers.

Maslow, A. 1943. A theory of human motivation. Psychological Review 50: 370- 396.

Mileti, D. 1999. Disasters by design: A reassessment of natural hazards in the United States. Washington, DC: J oseph Henry Press.

National Academy of Public Administration. 2007. Prioritizing America's water resources investments: Budget reform for civil works construction projects at the U.S. Army Corps of Engineers. Washington, DC.

National Civic League. 1999. The Civic Index. Denver, CO: National Civic League.

National Research Council. 1999. New directions in water resources: Planning for the U.S. Army Corps of Engineers. Washington, DC: National Academy Press. 
. 2002. Community and quality of life: Data needs for informed decision making. Washington, DC: National Academy Press.

. 2004a. River basins and coastal systems: Planning within the U.S. Army Corps of Engineers. Washington, DC: National Academy Press.

. 2004b. U.S. Army Corps of Engineers water resources planning: A new opportunity for service. Washington, DC: National Academy Press.

New Zealand Metropolitan Council. 2005. Quality of Life in New Zealand's Large Urban Areas (www.bigcities.govt.nz/ indicators.htm).

Noll, H. 2004. Social indicators and quality of life research: Background, achievements and current trends. Advances in sociological knowledge over half a century. $\mathrm{N}$. Gerov, ed., Wiessbaden, GE: Verlag für Sozialwissenschaften. Springer.

Oswald, A. 1997. Happiness and economic performance. Economic J ournal 107: 18151831.

Putnam, J . 1993. Making democracy work: Civic traditions in modern Italy. Princeton, NJ : Princeton University Press.

. 2000. Bowling alone: The collapse and revival of american community. New York: Simon and Schuster.

Rawls, J . 1971. A theory of justice. Boston: Harvard University Press.

Reuss, M. 2004. The development of American water resources: Planners, politicians, and constitutional interpretation. In Managing water resources: Past and present, The Linacre Lectures 2002, J . Trottier and P. Slack, ed., London: Oxford University Press.

Rogers, P. 1993. America's water. Cambridge, MA: MTT Press.

Rygel, L., D. O'Sullivan, and B. Yarnal. 2005. A method for constructing a social vulnerability index. Penn State University: Center for Integrated Regional Assessment.

Sanders, I. 1960. The community social profile. American Sociological Review 60(1).

Schad, T. 1986. Present policies and practices. In Social and environmental objectives in water resources planning and management. W. Viessman, J r., and K. Schilling, ed., New York: American Society of Civil Engineers.

Stakhiv, E. 1986. Achieving social and environmental objectives in water resources planning. In Social and environmental objectives in water resources planning and management. W. Viessman, Jr., and K. Schilling, ed., New York: American Society of Civil Engineers.

Stringer, E. 1999. Action research. Thousand Oaks, CA: Sage.

Swain, D. 2002. Measuring progress: Community indicators and the quality of life. J acksonville, FL: J acksonville Community Council, Inc. (www.jcci.org). 
United Nations. 1976. The Vancouver Action Plan. UN Conference on Human Settlements. Vancouver, Canada.

. 1992. The Dublin Statement on Water and Sustainable Development. UN International Conference on Water and the Environment. Dublin, Ireland.

U.S. Department of Health, Education, and Welfare. 1969. Toward a social report. Washington, DC: U.S. Government Printing Office.

University of Illinois, Department of Natural Resources and Environmental Science. 2006. A step-by-step guide to conducting a social profile for watershed planning. (http:// www.watershedplanning.uiuc.edu/index.html).

Viessman, W., Jr. 1998. Water policies for the future: An introduction. Water Resources Update. Spring.

Water Resources Council. 1973. Water and related land resources: Establishment of principles and standards for planning. Federal Register September 10, 1973.

. 1983. Economic and environmental principles and guidelines for water and related land resources implementation studies. Federal Register March 10, 1983.

Willeke, G. E. 1974. Identification of publics in water resources planning. OWRR Project, B-095-GA. Atlanta, GA: Georgia Institute of Technology.

Yoe, C. 2002. Trade-off analysis planning and procedures guidebook. IWR Report 02-R2. Fort Belvoir, VA: U.S. Army Corps of Engineers, Institute for Water Resources.

Young, R. 2005. Determining the economic value of water: Concepts and methods. Washington, DC: Resources for the Future. 


\section{Appendix A: Comparison of Key Theoretical OSE Concepts and Variables with Current OSE Variables}

\begin{tabular}{|c|c|c|}
\hline $\begin{array}{l}\text { Key Human Needs } \\
\text { Dimensions }\end{array}$ & Quality of Life Concepts and Variables & OSE Factors Listed in ER 1105-2-100 \\
\hline Health and Safety & Health and safety & $\begin{array}{l}\text {-Effects on security, life, health, and } \\
\text { safety } \\
\text {-Effects on emergency preparedness }\end{array}$ \\
\hline Material Well-Being & $\begin{array}{l}\text { Material well-being; economic } \\
\text { development and standard of living; } \\
\text { housing; built environment; natural } \\
\text { environment; job security }\end{array}$ & $\begin{array}{l}\text {-Long-term productivity effects including } \\
\text { maintenance and enhancement of } \\
\text { productivity of resources for use by } \\
\text { future generations } \\
\text {--Effects on the fiscal condition of the } \\
\text { State and local sponsor } \\
\text {--Effects on real incomes }\end{array}$ \\
\hline $\begin{array}{l}\text { Social Connectedness, } \\
\text { Identity, } \\
\text { Belongingness }\end{array}$ & $\begin{array}{l}\text { Social connectedness; people; family } \\
\text { relations and community life; civic } \\
\text { infrastructure }\end{array}$ & $\begin{array}{l}\text {-Urban and community impacts } \\
\text {--Effects on population distribution and } \\
\text { composition } \\
\text {--Displacement of people, businesses, } \\
\text { and farms }\end{array}$ \\
\hline \multicolumn{3}{|l|}{$\begin{array}{l}\text { Status, Recognition, } \\
\text { Esteem, Identity }\end{array}$} \\
\hline \begin{tabular}{|l|} 
Distributive Justice, \\
Fairness, Participation
\end{tabular} & $\begin{array}{l}\text { Civil and political rights; political freedom; } \\
\text { political stability and security; gender } \\
\text { equality; knowledge and skills; social } \\
\text { vulnerability }\end{array}$ & $\begin{array}{l}\text {--Effects on employment distribution, } \\
\text { especially the share to minorities } \\
\text {--Effects on educational, cultural, and } \\
\text { recreational opportunities } \\
\text {-Other effects as relevant }\end{array}$ \\
\hline
\end{tabular}




\section{Appendix B: A Brief History of Congressional and Executive Branch Concern with Social Effects}

The evolution of water resources principles and procedures is in itself a fascinating subject. (See, for example, Reuse 2000; NRC 1999; Schad 1986; Caulfield 2000; Rogers 1993). For the purposes of this report, it is worth noting that as early as Senate Document 97 in 1962 the "Well-Being of People" was seen as a basic objective in the formulation of plans:

Hardship and basic needs of particular groups was to be of concern, but development for the benefit of the few or the disadvantage of the many was to be avoided. In accordance with this objective, socioeconomic policy requirements established by the Congress were to be observed (e.g. the 160 -acre rulein relation to federal supply of water for irrigation and 'preference clauses' relating to the sale of federal power to public and rural electric cooperatives). Also, 'well-being of people' was an objective that could take into account the saving of life by a flood control project, while savings from property damage would be taken to be a benefit in furtherance of the developmental objective (Caulfield 2000). ${ }^{1}$

Later in the Flood Control Act of 1970 (PL 91-611), Congress declared its intent concerning the importance of multiple objectives for water resources development. Section 209 of this Act states:

It is the intent of Congress that the objectives of enhancing regional economic development; the quality of the total environment, including its protection and improvement; the well-being of the people of the United States; and the national economic development are the objectives to be included in federally financed water resources projects, and in the evaluation of benefits and costs attributable thereto,

\footnotetext{
1 Henry Caulfield was the principle author of Senate Document 97, while serving as Chair of the Interdepartmental Staff Committee of the Ad Hoc U.S. Water Resources Council.
} 
giving due consideration to the most feasible alternative means of accomplishing these objectives (U.S. Congress 1970).

Additionally, Section 122 of the same Act provides a listing of the effects that Congress believed necessary to consider in determining the public interest for making water resources investments:

Not later than J uly 1, 1972, the Secretary of the Army, acting through the Chief of Engineers, after consultation with appropriate Federal and State officials shall submit to Congress, and not later than ninety days after submission, promulgate guidelines designed to assure that possible adverse economic, social and environmental effects relating to any proposed project have been fully considered in developing such project and that the final decisions on the project are made in the best overall public interest, taking into consideration the need for flood control, navigation and associated purposes, and the cost of eliminating or minimizing such adverse effects, and the following:

1. Air, noise, and water pollution;

2. destruction or disruption of man-made and natural resources, esthetic values, community cohesion and the availability of public facilities and services;

3. adverse employment effects and tax and property value losses;

4. injurious displacement of people, businesses, and farms; and

5. disruption of desirable community and regional growth (U.S. Congress 1970).

The Executive Branch, acting through the Water Resources Council, promulgated the Principles and Standards for Planning Water and Related Land Resources in 1973. In large measure, the P\&S followed Congressional intent; however, instead of four co-equal objectives for water resources plans, P\&S had two - national economic development and environmental quality. The social well-being, and regional economic development accounts were described as "Other Beneficial and Adverse Effects" and were to be displayed where appropriate. In P\&S the following constituted the variables of interest in the Social Well-Being account: 
1. Real income distribution: The effects of a plan on the real income of classes or groups that are relevant to the evaluation of a plan will be displayed. All effects, both monetary and income in kind, will be included in the display.

2. Life, health, and safety: Plan effects on life, health, and safety other than those evaluated monetarily for the national economic development objective will be included here. Measurement techniques will vary but would largely be in terms of physical units.

3. Educational, cultural, and recreational: The effects of the plan on educational, cultural, and recreational opportunities.

4. Emergency preparedness: The effect of the plan on reserve capacities and flexibilities in water resources systems and protection against interruption of the flow of goods and services at times of national disaster or critical need will be displayed.

5. Other: Other effects on social well-being may be identified and displayed as relevant to alternative plans (Federal Register 1973).

Congress was not completely satisfied with this partial implementation of its intent, however, and further directed that its original intent be heeded. Section 80c of the 1974 Water Resources Development Act ordered:

(c) The President shall make a full and complete investigation and study of principles and standards for planning and evaluating water and related resources projects. Such investigation and study shall include, but not be limited to, consideration of enhancing regional economic development, the quality of the total environment including its protection and improvement, the well-being of the people of the United States, and the national economic development, as objectives to be included in federally financed water and related resources projects and in the evaluation of costs and benefits attributable to such projects, as intended in section 209 of the Flood Control Act of 1970 (84 Stat. 1818, 1829), the interest rate formula to be used in evaluating and discounting future benefits for such projects, and appropriate Federal and non-Federal cost sharing for such projects. He shall report the results of such investigation and study, together with his recommendations, to Congress, not later than one year after fun are first appropriated to carry out this subsection. 
In 1983, the P\&S were repealed by the Water Resources Council and replaced by the Economic and Environmental Principles and Guidelines for Water and Related Land Resources Implementation Studies (P\&G). "They were removed from the "Rules" section of the Federal Register and placed in the "Notices" section, thus becoming guidelines rather than rules for Federal agency planning (NRC 1999)." Shortly thereafter the Water Resources Council was defunded by the Reagan Administration, and the responsibility for the P\&G moved to OMB.

$P \& G$ removed environmental quality as a federal objective, leaving national economic development as the sole Federal objective for water resources development, consistent with protecting the Nation's environment, pursuant to national environmental statutes, applicable executive orders, and other Federal planning requirements (P\&G 1983)" The four-account structure from P\&S remained in $P \& G$; however, $P \& G$ noted that the NED account is the only required account for display. The Other Social Effects account (changed from the Social Well-Being account under P\&S) was to display urban and community impacts and effects on life, health and safety. The specific variables of interest listed in the account were:

- Urban and community impacts

o Income distribution;

o Employment distribution, especially the share to minorities;

o Population distribution and composition

o Fiscal condition of the State and local governments

o Quality of community life

- Life, health, and safety

- Displacement effects

- Long-term productivity (P\&G) 


\section{Appendix C: Toward a Collaborative Planning Paradigm}

\section{Drivers toward collaborative planning}

There is general (broad) agreement within the water resources community that systems-oriented planning at a watershed scale is needed to adequately manage water resources. A quote from a water resources expert is illustrative of this perspective (Viessman 1998):

Water policies for the 21st Century should have the following attributes:

- They should focus on the right "problemshed." That is, they should be system-encompassing, to assure that policy boundaries are defined by their true temporal, spatial, environmental, and institutional dimensions.

- They should be flexible; standardized, uniform formats for dealing with water management should be avoided. The key is to look for the approach that works for the problemshed and problem to be addressed.

- They should be holistic, considering all of the relevant interacting components of the system of concern.

- They should be designed to support sustainable development.

- They should embrace public views.

- They should encourage partnership approaches to resolving conflicts and designing water management strategies.

- They should be the driving force for regulatory programs, not the result of them.

There is also broad support among water resources stakeholders for the concepts and principles of a watershed approach to water resources management. In 2000 the Corps of Engineers conducted 16 "Listening Sessions" at locations throughout the United States to provide citizens the opportunity to voice concerns about pressing water resources needs, problems and opportunities. Over 2,000 stakeholders attended the sessions and provided more than 3,400 concerns. The concerns were 
grouped into 10 themes or challenges. One of the 10 challenges was "Managing Watersheds Holistically." The report presenting the water resources challenges provided several summary statements about watershed management (U.S. Army Corps of Engineers 2001):

- Generally people felt that decision makers should analyze water resources comprehensively and at a watershed level prior to taking any actions within the watershed.

- Participants at the Listening Sessions expressed the need for the Federal government to plan and manage watersheds holistically in the following ways:

o Seek water resources solutions for ecosystem restoration and environmental sustainability along with economic development.

o Provide 100 percent federal funding and technical expertise to assist watershed planning efforts.

o Coordinate watershed planning involving all stakeholders and agencies (federal, state, and local).

o Change legislative authorization and resource allocation to promote regional planning.

o Help identify watershed-level goals that can be implemented locally.

The Corps' Civil Works Strategic Plan also commits the Corps to "responding to the nation's water resources challenges through integrated water resources management and a watershed focus" (U.S. Army Corps of Engineers 2004), and highlights four key components of this direction: systems approaches, spatial or geographical integration, balance across multiple uses or functions, and employing collaborative approaches (pp. 6- 7). Similarly, the Corps Policy Guidance Letter 61, Planning in a Watershed Context, lays out an ambitious policy for incorporating a watershed perspective into Corps planning (U.S. Army Corps of Engineers 1999) noting that the analytical framework for plans will be "founded on factual scientific, social, and economic information, allowing for the assessment, evaluation, and comparison of alternative plans, including positive and negative effects on economic development, the environment, and social well-being." 
The Corps' Engineering Circular (EC) 1105-2-409, issued in 2005, lays out the clearest expression of the Corps' intent to change its planning process to embrace the watershed principles expressed in Policy Guidance Letter 61 and the Civil Works Strategic Plan. The EC makes several major changes in Corps planning policy:

- Collaborative planning activities with other Federal agencies and embracing solutions that reflect issues beyond traditional Corps responsibilities will be given budget priority;

- Plans no longer need recommend the NED plan (though cost-sharing policies concerning NED plans remain in effect). Any alternative plan may be selected if, on balance, it has net beneficial effects in the four $P \& G$ accounts. Planning reports must discuss and display the beneficial and adverse effects of each plan in each P\&G account and compare the effects across plans.

Finally, as a result of a broad reexamination of Corps policies and approaches in the aftermath of Hurricane Katrina, the Chief of Engineers issued his "12 Actions for Change" (U.S. Army Corps of Engineers 2006). The 12 actions are organized into three key themes:

- A comprehensive systems approach: comprehensively design, construct, maintain and update engineered systems to be more robust, with full stakeholder participation;

- Communication: effective and transparent communication with the public, and within the Corps, about risk and reliability;

- Reliable public service professionalism: improve the state of the art and the Corps' dedication to a competent, capable workforce on a continuing basis. Make the commitment to being a "learning organization" a reality.

\section{Inhibitors}

While the Corps documents referenced here certainly provide an indication that holism, collaboration, and systems approaches are desired in water resources planning, there are, nevertheless, several strong inhibitors that work against such a paradigm shift. Chief among these inhibitors is the fiscal policy of OMB. In the past, this budget policy has been almost exclusively focused on the use of benefit-cost metrics to prioritize construction new starts and continuing projects. Budgeting policies now also give weight to projects that address significant risks to 
human safety (Department of the Army 2006, Appendix 4). With current OMB budgeting policies, projects formulated on criteria other than NED may not be considered for funding in the President's Budget even if they are authorized and rise through internal Corps budget evaluation processes. Another key inhibitor that the Corps must confront is the unfamiliarity of Corps planners, and others in the plan approval and budgeting apparatus, with the new planning concepts and the skepticism and inertia regarding their implementation that such unfamiliarity can breed. In contrast to the OMB constraint, this is one area that the Corps can do something about through a vigorous program of education and engagement within the workforce to clarify and explore the meaning of the guidance that has been developed. 


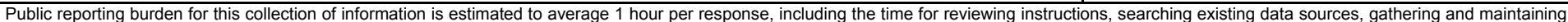

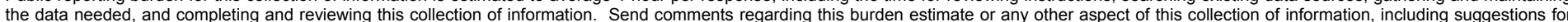

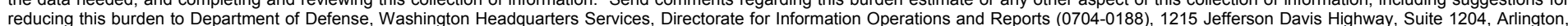

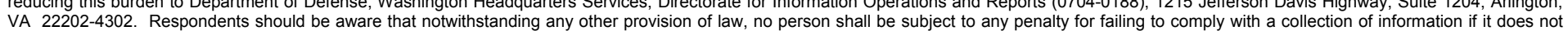
VA 22202-4302. Respondents should be aware that notwithstanding any other provision of law, no person shall be sube
display a currently valid OMB control number. PLEASE DO NOT RETURN YOUR FORM TO THE ABOVE ADDRESS.

\begin{tabular}{l|c}
$\begin{array}{l}\text { 1. REPORT DATE }(D D-M M-Y Y Y Y) \\
\text { September } 2007\end{array}$ & $\begin{array}{c}\text { 2. REPORT TYPE } \\
\text { Final report }\end{array}$ \\
\hline
\end{tabular}

\section{TITLE AND SUBTITLE}

Theoretical Underpinnings of the Other Social Effects Account

3. DATES COVERED (From - To)

5a. CONTRACT NUMBER

5b. GRANT NUMBER

5c. PROGRAM ELEMENT NUMBER

6. AUTHOR(S)

C. Mark Dunning and Susan Durden 5d. PROJECT NUMBER

5e. TASK NUMBER

5f. WORK UNIT NUMBER

8. PERFORMING ORGANIZATION REPORT NUMBER

ERDC/CHL SR-07-1

10. SPONSOR/MONITOR'S ACRONYM(S)

11. SPONSOR/MONITOR'S REPORT NUMBER(S)

\section{DISTRIBUTION / AVAILABILITY STATEMENT}

Approved for public release; distribution is unlimited.

\section{SUPPLEMENTARY NOTES}

\section{ABSTRACT}

While water resources planning has primarily been focused on enhancing economic well-being as portrayed in the National Economic Development (NED) account, well-being is a multifaceted concept grounded in human needs that includes distributive justice, social connectedness, equality, and health and safety considerations, in addition to economic well-being factors. Information on these multiple dimensions of well-being is increasingly being used by Federal agencies, the World Bank, and other countries to provide a more comprehensive understanding of quality of life and livability issues. A water resources planning process that incorporates a multidimensional conception of well-being positively influences the degree to which water resources solutions will be judged as effective, acceptable, and fair. The planning process envisioned in the U.S. Army Corps of Engineers' Engineering Circular on collaborative planning is consistent with the conceptions of well-being portrayed in this paper. To be most effective in this emerging planning framework, social factors information addressed in the "Other Social Effects" (OSE) account should be integrated into the planning process to provide information about social issues of concern to help shape planning objectives, develop and evaluate alternatives, and work toward solutions. The role of the OSE practitioner should be one of "action researcher," helping all interested parties to use OSE information to contribute to decision-making.

(Continued)

\section{SUBJECT TERMS}

(See reverse.)

16. SECURITY CLASSIFICATION OF:

a. REPORT

UNCLASSIFIED

b. ABSTRACT
UNCLASSIFIED

c. THIS PAGE

UNCLASSIFIED

\begin{tabular}{|l|c|}
\hline $\begin{array}{l}\text { 17. LIMITATION } \\
\text { OF ABSTRACT }\end{array}$ & $\begin{array}{c}\text { 18. NUMBER } \\
\text { OF PAGES }\end{array}$ \\
& 54 \\
&
\end{tabular}

19a. NAME OF RESPONSIBLE PERSON

19b. TELEPHONE NUMBER (include area code) 


\section{ABSTRACT (continued)}

A number of actions will be needed to ensure that OSE information is substantively used in water resources planning. Training and policy clarification forums will be necessary to overcome the lack of understanding and skepticism among planners steeped in NED-centric planning about OSE information and its value. Frameworks will need to be evaluated and defined which incorporate OSE in the decision-making process. Establishing an OSE center of expertise within the Corps of Engineers would also help in raising the profile of human factors information and would establish a base for advancing water resources-oriented human factors knowledge. Finally, the Corps needs to re-engage with the growing body of practice in human dimensions, social factors, and quality of life work located in other Federal agencies, the World Bank, the European Union, other organizations, and academia.

\section{SUBJECT TERMS}

Four accounts

Human dimensions

Multidimensional

National economic development

Other social effects

Planning

Quality of life

Social factors

Well-being 